\title{
Chemosymbiotic bivalves from the late Pliocene Stirone River hydrocarbon seep complex in northern Italy
}

\author{
Steffen Kiel and Marco Taviani \\ Acta Palaeontologica Polonica 63 (3), 2018: 557-568 doi:https://doi.org/10.4202/app.00473.2018
}

Seven species of chemosymbiotic bivalves are described from the late Pliocene Stirone River hydrocarbon seep complex in northern Italy, including one new species and two in open nomenclature. The known species are the solemyid Acharax doderleini, the lucinids Lucinoma persolida and Megaxinus ellipticus, and the vesicomyid Isorropodon aff. perplexum; in open nomenclature we report two lucinids, including the largest species of Lucinoma known from the Italian Pliocene to date, and a strongly inflated, large Anodontia sp. The most abundant species at the Stirone seep complex is the lucinid Megaxinus stironensis sp. nov. This Pliocene seep fauna differs from that of the well-known Miocene "Calcari a Lucina" seep deposits by lacking large bathymodiolin mussels and vesicomyid clams; instead, the dominance of the lucinid Megaxinus stironensis gives this fauna a unique character. We speculate that at the Stirone seep complex, Megaxinus had occupied the ecological niche that Meganodontia occupied at the Miocene "Calcari a Lucina" seep sites in the Mediterranean basin, and that the dominance of Megaxinus could be a wide-spread feature of Pliocene chemosynthesis-based ecosystems in Mediterranean Pliocene.

Key words: Bivalvia, Lucinidae, Vesicomyidae, hydrocarbon seep, chemosymbiosis, Pliocene, Italy, Apennines.

Steffen Kiel [steffen.kiel@ nrm.se], Swedish Museum of Natural History, Department of Palaeobiology, Box 50007, 10405 Stockholm, Sweden.

Marco Taviani [marco.taviani@bo.ismar.cnr.it], Institute of Marine Sciences, Italian National Research Council, Via Gobetti 101, 40129 Bologna, Italy; Stazione Zoologica Anton Dohrn, Villa Comunale, 80121 Napoli, Italy, and Biology Department, Woods Hole Oceanographic Institution, 266 Woods Hole Rd, Woods Hole, MA 02543, USA.

This is an open-access article distributed under the terms of the Creative Commons 
Attribution License (for details please see creativecommons.org), which permits unrestricted use, distribution, and reproduction in any medium, provided the original author and source are credited.

PoFif Full text $(989.6 \mathrm{kB})$ 